\title{
Seasonal Behavior of Aerosol Vertical Concentration in Dakar and Role Played by the Sea-Breeze
}

\author{
Habib Senghor ${ }^{*}$, Éric Machu², Luis Durán³, Gregory S. Jenkins4 ${ }^{4}$, Amadou Thierno Gaye1 \\ ${ }^{1}$ Laboratoire de Physique de l'Atmosphère et de l'Océan Siméon-Fongang (LPAO-SF), École Supérieure Polytechnique (ESP), \\ Université Cheikh Anta Diop (UCAD), Dakar, Sénégal \\ ${ }^{2}$ Laboratoire d'Océanographie Physique et Spatiale (LOPS), Institut Universitaire Européen de la Mer (IUEM), Plouzané, France \\ ${ }^{3}$ InterMET, Madrid, Spain \\ ${ }^{4}$ Department of Meteorology and Atmospheric Science, University Park, State College, PA, USA \\ Email: ^habib.senghor@ucad.edu.sn
}

How to cite this paper: Senghor, H., Machu, É., Durán, L., Jenkins, G.S. and Gaye, A.T. (2020) Seasonal Behavior of Aerosol Vertical Concentration in Dakar and Role Played by the Sea-Breeze. Open Journal of Air Pollution, 9, 11-26. https://doi.org/10.4236/ojap.2020.91002

Received: December 11, 2019

Accepted: February 1, 2020

Published: February 4, 2020

Copyright $\odot 2020$ by author(s) and Scientific Research Publishing Inc. This work is licensed under the Creative Commons Attribution International License (CC BY 4.0).

http://creativecommons.org/licenses/by/4.0/

\begin{abstract}
The Westward transport of mineral dust from the North Africa continent to Atlantic Ocean can produce poor air quality, low visibilities, and negatively impacting respiratory and cardiac health due to the optical and physical properties of aerosols. The dynamical impact of the sea-breeze on the dust vertical distribution in West Africa remains unknown. To investigate this issue, we have used in-situ measurements from lidar. We have focused on the attenuated backscatter of aerosols to study the effect of the local circulation on the vertical profile of mineral dust at land-sea transition. The results highlight a strong diurnal cycle of mineral dust associated with the nocturnal low-level jet (NLLJ). The jet is located between $500 \mathrm{~m}$ and $1000 \mathrm{~m}$ and crucially affected by the dynamic of the sea-breeze circulation.
\end{abstract}

\section{Keywords}

Aerosols, Dust, Sea-Breeze, Circulation

\section{Introduction}

Desert aerosols from arid and semi-arid areas located in North Africa are suspended in the atmosphere. The mineral dust exported from the northern hemisphere represents almost one billion tons per year [1] corresponding to $70 \%$ of the aerosol mass annually lifted around the world and six times more than the second largest source, Asia [2]. The desert aerosols have a significant impact on 
the climate via the Earth radiative budget [3]. Aerosols can also negatively influence the human health through respiratory and cardiac diseases [4] [5] [6]. The World Health Organization evaluated the premature deaths, due to the atmospheric aerosol loading approximately 800,000 deaths each year.

Moulin et al. [7] found a strong correlation between dust transported over North Africa and the climate variability of the North Atlantic Oscillation (NAO). Chiapello et al. [8] and Prospero et al. [9] have found a strong increase of African dust emissions since 1970s. This enhancement of dust emissions has been attributed mainly to the drought, in the Saharan-Sahel area, caused by changes in the global distribution of Sea Surface Temperature (SST) [10]. The SST is a key parameter on the vertical distribution of desert aerosols in West African coastlines. This link can be explained by the strong interactions between surface land, ocean and the atmosphere [11]. The Western African coastlines are determined by a strong interaction of westward flows from meso-scale and a local sea-breeze circulation [12]. The latter is one of the most familiar dynamical phenomena recording at the coastal regions all around the world [13]. The sea-breeze circulation is often associated to the onshore advection in the lowermost atmospheric layer bringing a clear air masses flux that induced a lower-mixed-layer height [14]. During the field campaign of SaHAran Dust Over West Africa (SHADOW), carried out from March to June 2015 and which has done at coastal site at Mbour (Senegal), Rivellini et al. [15] related a decreasing of aerosol concentration inducing by the sea-breeze phenomena. Rivellini et al. [15] defined the period from March to April with the maximum sea-breeze occurrence frequency. They have shown that the wind direction was dominated by the northwest regime ( 62\%) with some occurrences $(\sim 33 \%)$ of western winds. Schepanski et al. [16] pointed out an important effect of the breakdown of the NLLJ in dust mobilization in West Africa. They related that $65 \%$ of dust sources activation occurs during nighttime (06 - 09 UTC). Their results, which indicated the role of the NLLJ in dust mobilization in the Sahara, were corroborated by regional model studies and analysis of meteorological station data [16]. Their study is limited in terms of the vertical distribution of dust transport from Saharan-Sahel sources in the Easterly LLJ (ELLJ). Heese et al. [17] showed a heavy dust loading in the ELLJ in nighttime during AMMA field campaign above the land surface level (Niamey, Niger). In the early morning, aerosols contained in the ELLJ layer are dispersed into the developing boundary layer. This study, which has done in the middle area of Sahel region, is a typical case study for the areas located far from the Ocean. In the African coastal, the vertical distribution of aerosol during daytime can be affected by local atmospheric circulation. Petzold et al. [12], using an aircraft measurements, assumed that the dilution of dust plumes over Dakar is due to the local circulation. This case study can not be representative for the global influence of the dynamic on the vertical distribution of the aerosols, because it just covered a very short range time scale.

Regarding the effects of atmospheric aerosol loading on public health, it be- 
comes very urgent to reduce the lack of information on the temporal variability of mineral dust mainly over North Africa. In this area, the population has been suffered from dust events consequences [6] [18]. Hence, Choobari et al. [19] emphasized the lack of studies on the diurnal and seasonal variability of the vertical distribution of mineral dust over the greatest dust source regions, around the globe, and dust transport along their pathways.

Based on the knowledge taken from the state of the art of aerosol vertical distribution such as conceptual scheme of the mechanisms controlling the Saharan atmospheric boundary layer structure and the dust vertical redistribution developed by Cuesta et al. [20], we investigate the diurnal and seasonal meteorological processes behind the shift of the aerosol layer in the Sahel area. This study aims to reduce uncertainties of local dynamic impact on the seasonality of desert dust transport in West Africa coastal.

The present work is organized as follows: Section 1 is attributed to the introduction. Section 2 represents observations used for this study. In section 3, we focus on the analysis of results. Section 4 discusses the main results and Section 5 is dedicated to the conclusion.

\section{Datasets}

\subsection{Ceilometer (CL31)}

We use a lidar also called ceilometer (CL31) installed in Dakar since April 2012 in collaboration with Howard University and Universidad Complutense de Madrid. The vaisala manufactured lidar is based on an eye safe laser InGaAs diode at wavelength $905 \mathrm{~nm}$, sending pulses out along the zenital direction with an energy per pulse of $1.2 \mu \mathrm{J} \pm 20 \%$ [21] [22]. The ceilometers can efficiently detect the height of the boundary layer [23] [24] [25]. For the detection, the ceilometer uses a one lens system with overlapping transmitting and receiving optics, the beam overlap occurs at shallower altitude, providing nearly full overlap of the transmitter and the receiver field-of-view at altitude above $30 \mathrm{~m}$ [21]. An inclined mirror provides the separation between transmitting and receiving areas with a hole in the center. The half-angle beam divergence for our ceilometer measures $0.75 \mathrm{mrad}$ and has $0.66 \mathrm{mrad}$ for the half-angle field of view. This lidar has a measurement range from 0 to $7500 \mathrm{~m}$ above sea level (asl), with a high temporal resolution (16 seconds, 5400 profiles per day) and high vertical resolution $(10 \mathrm{~m})$. The ceilometer combined to the Boundary Layer View Software (BL-View) provides a good vertical profile of the attenuated backscatter signal of aerosols [26]. This instrument is used to get information from the different atmospheric component as cloud base height, atmospheric aerosol loading and the level of the atmospheric boundary layer [22].

For the comparison, a spectral conversion becomes necessary for the groundbased measurements from $905 \mathrm{~nm}$ to $532 \mathrm{~nm}$ wavelength. First, the attenuated backscatter coefficient was calculated by interpolation to match the Cloud-Aerosol Lidar with Orthogonal Polarization (CALIOP) extinction profile at $532 \mathrm{~nm}$ us- 
ing the following formula which has been taken from Tsaknakis et al. [22]:

$$
b_{\lambda_{1}}=b_{\lambda_{2}} \cdot \mathrm{e}^{-\ln \left(\lambda_{1} / \lambda_{2}\right) \cdot c(z)}
$$

Here, $b_{\lambda_{1}}$ and $b_{\lambda_{2}}$ are respectively the attenuated backscatter coefficient at wavelength $\lambda_{1}$ and $\lambda_{2}$, c represents the Ångström wavelength exponent. The latter parameter has taken from Sun photometer AErosol RObotic Network (AERONET) at Dakar station.

The extinction coefficient was derived from the total attenuated backscatter profiles $b(z)$ using a standard extinction lidar inversion technique, which can be expressed as follows:

$$
b(z)=k \cdot \sigma(z)
$$

where $k=0.03 \mathrm{sr}^{-1}$ is a constant particle backscatter to extinction ratio [27] [28] representative of aerosols particles. $\sigma(z)$ is the extinction coefficient [26]. According to Eck et al. [29], the monthly diurnal variability showed is computed when a threshold of nine days measurements is available for each month (Figure 3).

In 2012, only data from April to September are available. In year 2013, the data for February, March, June, September, October, November and December are available. In year 2014, only data from October, November and December are missing.

\subsection{CALIPSO}

CALIPSO belongs to the Afternoon satellite constellation (A-Train) that was launched by the National Aeronautics and Space Administration (NASA) in association with Centre National d'Etudes Spatiales (CNES) on 28 April 2006 [30]. The platform of CALIPSO has a high resolution CALIOP, $60 \mathrm{~m}$ in the lower levels. CALIOP is an elastic-backscatter lidar with a dual-wavelength polarization lidar (532 and $1064 \mathrm{~nm}$ ). It has three receiver channels that measure the backscatter intensity at $532 \mathrm{~nm}$, polarized $532 \mathrm{~nm}$, and $1064 \mathrm{~nm}$ wavelengths with pulse energy of $110 \mathrm{~mJ}$ and a frequency of $20.25 \mathrm{~Hz}$ [31]. In this paper, we used desert dust extinction coefficient profiles at $532 \mathrm{~nm}$ to evaluate the ceilometer vertical profile for three years period from 2012 to 2014 when maximum data retrieval is available. The Level 3 aerosol profiles (monthly product) with a $2^{\circ}$ latitude $\times 5^{\circ}$ longitude resolution and $60 \mathrm{~m}$ vertical resolution are downloaded from http://www.icare.univ-lille1.fr/drupal/archive/ and are used to evaluate the annual cycle of the atmospheric dust loading aerosol over the transition zone between continent and ocean.

\subsection{Weather Observations}

The vertical profile of local wind (velocity and direction) were obtained at the weather station located at Dakar-Yoff $\left(14^{\circ} 73^{\prime} \mathrm{N}, 17^{\circ} 5^{\prime} \mathrm{W} ; 24 \mathrm{~m}\right.$ asl $)$ [32]. We use three years of data from January 2012 to December 2014. The radio sounding data published online by the Wyoming University are downloaded from http://weather.uwyo.edu/upperair/sounding.html. 
We also used the horizontal wind vector measurements (direction and speed) made at $30 \mathrm{mn}$ intervals at the International Airport of Dakar-Yoff, Senegal. The station is located at $14^{\circ} 44^{\prime} \mathrm{N}, 17^{\circ} 30^{\prime} \mathrm{W}$ and $27 \mathrm{~m}$ ASL [33]. This aviation surface weather information was provided in http://www.ogimet.com/metars.phtml.en.

\section{Methodology}

A typical dust diurnal cycle in West Africa is displayed on 11 April 2012 (Figure 1). The CL31 is not able to give the volume depolarization ratio to distinct the signal from different aerosol types. The NOAA HYSPLIT MODEL Backward trajectories ending at Dakar at 23 UTC (not shown) on the day before indicate that the residual layer of aerosols located between 1000 and $4000 \mathrm{~m}$ could be composed by Saharan dust and biomass burning. The trajectories calculated with the HYSPLIT transport model ending over Dakar at the level $3000 \mathrm{~m}$ asl and coming from Guinea Golf countries was dominated by the biomass burning [34]. The aerosol layers ending over Dakar below $2000 \mathrm{~m}$ shown by the HYSPLIT model was particularly coming from the Sahara. The vertical distribution of atmospheric particles between two aerosol types in the troposphere was already observed by Heese et al. [17]. Despite the important quantity of the black

(a)
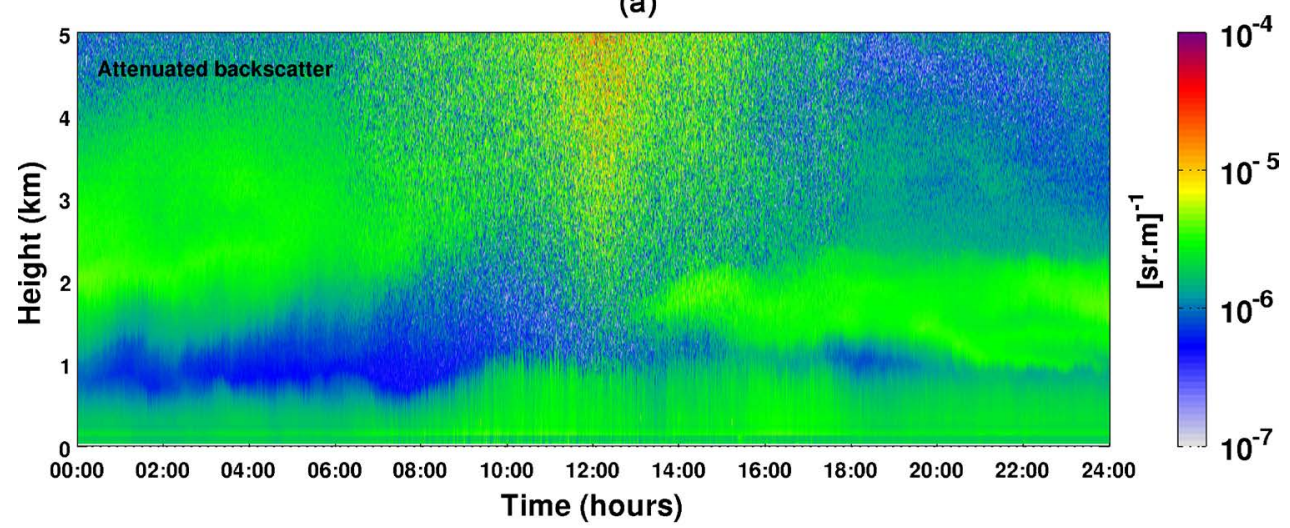

(b)

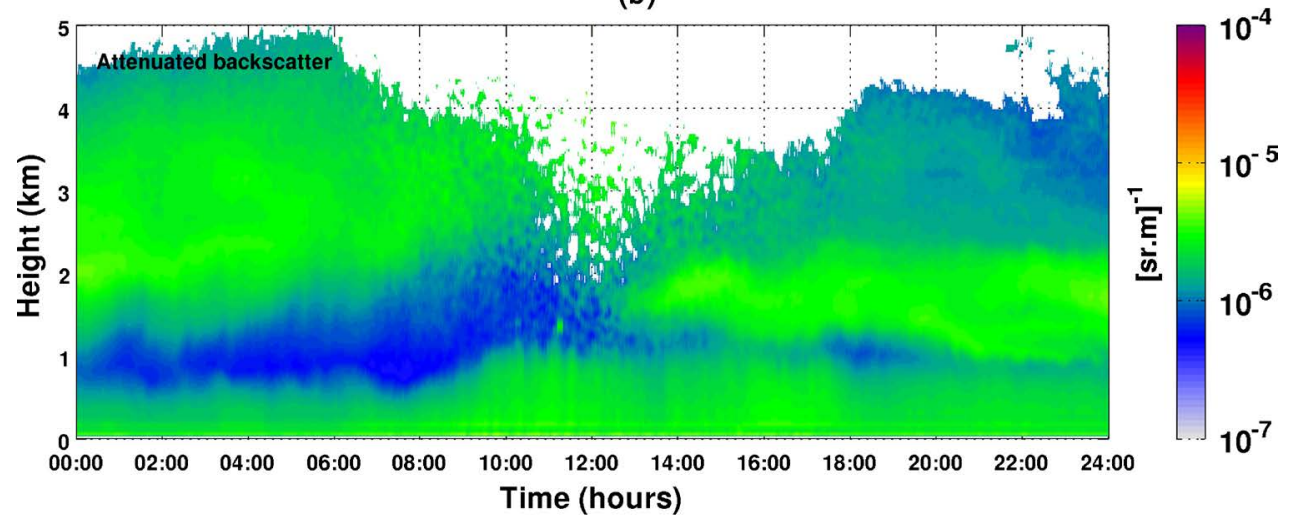

Figure 1. Lidar attenuated backscatter profile recorded on 11 April 2012 (Dakar, Senegal). The raw signal and sliding average of attenuated backscatter profile (30 profiles, 3 gates) are respectively shown on the top (Figure 1(a)) and the bottom (Figure 1(b)) panel. The residual layers are visible up to a height of $1000 \mathrm{~m}$. 
carbon emitted in Dakar [35], dust is a major component of aerosol loading between the near surface and $2000 \mathrm{~m}$ ASL [34] [36] [37]. In the following sections, we will consider that attenuated backscatter signal from aerosol was dominated by mineral dust over Dakar.

Figure 1(a) shows that the noise introduced by photons of the sky background increased at noon [38] up to $2000 \mathrm{~m}$ and it was reducing the quality measurement of dust loading during daytime. Despite the great capacity of the lidar to sound the troposphere, it was very important to emphasize that the Light Amplification by Stimulated Emission of Radiation (Laser which is used within to detect aerosols layers) is limited up to around $3000 \mathrm{~m}$ height due to the sky background [17] [21] [39]. The ceilometer signal-to-noise ratio (SNR) above $2500 \mathrm{~m}$ is too weak to allow for the detection of atmospheric components other than clouds. That's why its performance for investigating aerosols vertical distribution is limited between the surface and $2000 \mathrm{~m}$ asl. In order to overcome the parasite information from mainly sky artifacts, we improved the aerosol detection by smoothing the level-2 data (Figure 1(b)) with a running means of 30 profiles and 3 vertical gates $(30 \mathrm{~m})$ ).

\section{Validation of Extinction Coefficient Profiles in Dakar}

In this section, we compare measurements from CALIOP and CL31 in terms of vertical profile extinction for dust aerosol at $532 \mathrm{~nm}$ wavelength.

The CL31 provides a total attenuated backscatter coefficient from all types of aerosols in the atmosphere and for CALIOP, only the extinction from desert dust aerosols is retrieved (Figure 2).

In winter (December-January and February, DJF), the profiles from both lidars are very similar with a good the correlation (Figure 2(a)). However, the

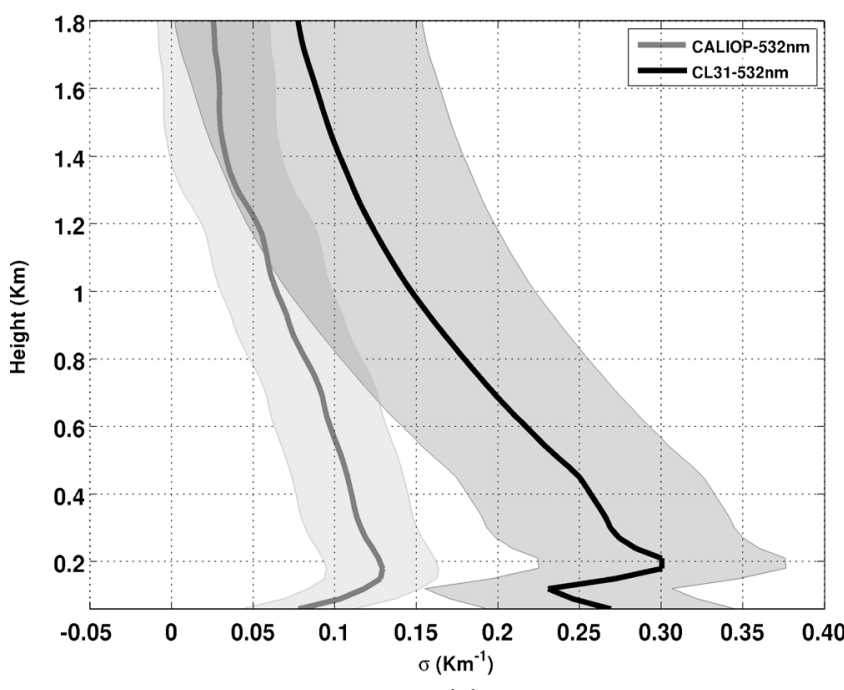

(a)

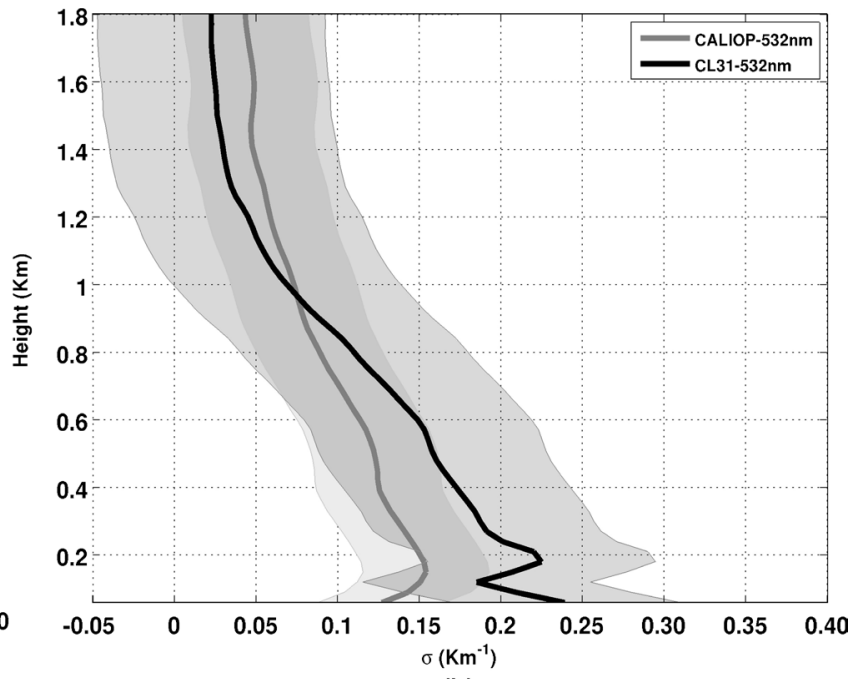

(b)

Figure 2. Seasonal averaged of dust extinction coefficient profiles $\left(\mathrm{km}^{-1}\right)$ at $532 \mathrm{~nm}$ in Dakar retrieved from CALIOP lidar in gray lines and CL31 in black lines between 2012 and 2014. DJF and MAM are respectively represented on the left (Figure 1(a)) and right panel (Figure 1(b)). 
spatial lidar underestimates the extinction near the surface compared to the ground measurements. This difference between both profiles can partly be explained by the lower resolution of CALIPSO $\left(2^{\circ} \times 5^{\circ}\right)$. Indeed, the low resolution of the satellite measurements cannot clearly detect the contribution of local boundary layer on the atmospheric dust loading.

In spring (March-April-May, MAM), both profiles are very also similar with a very good correlation (Figure $2(\mathrm{~b})$ ). In this season, the extinction values provided by the CL31 in the lowermost atmosphere indicate a weaker attenuated backscatter coefficient of the aerosols than in winter.

\section{Annual Cycle}

A clear seasonal cycle of vertical dust distribution over West Africa coastal is shown in this section.

\subsection{December to February}

In DJF, the seasonality of the diurnal cycle shows a maximum aerosol loading at daytime from sunrise 09 UTC to sunset 18 UTC (Figures 3(a)-(c)). The enriched aerosol layer increase from $500 \mathrm{~m}$ up to $1000 \mathrm{~m}$ asl between 12 UTC and 15 UTC. In this range time, the diurnal convection of the atmospheric boundary layer induced a growing thickness of the Mixed Atmospheric Boundary Layer (MABL) indicated by a vertical displacement of the enriched aerosol layer. After 18 UTC, the aerosol thickness of the boundary layer starts to decrease while the radiative forcing also diminishes at the land surface. As a consequence, the aerosols contained in the MABL are confined to the lowermost levels of atmosphere (i.e. between surface and $500 \mathrm{~m}$ height). The air mass becomes clearer above $500 \mathrm{~m}$ during nighttime and $1000 \mathrm{~m}$ daytime.

\subsection{March to May}

In MAM, the structure of the atmosphere is different compare to the situation of DJF which described in the previous subsection. Indeed, the MABL aerosol layers increases during nighttime through in MAM (Figure 3(d), Figure 3(e) and Figure 3(f)). The dust loading in the troposphere is higher during nighttime than daytime in the lowest part of the atmosphere between surface and $1000 \mathrm{~m}$ asl (Figure 3(d), Figure 3(e), Figure 3(f)). The aerosols attenuated backscatter signal is stronger between 500 and $1000 \mathrm{~m}$ asl than below $500 \mathrm{~m}$ during nighttime. The aerosol layer starts a progressive rising at 06 UTC at the altitude between $500 \mathrm{~m}$ and $1000 \mathrm{~m}$ (Figure 3(d)). This apparent shift of the dust plumes is due to the sea-breeze circulation in the West African coastal [12]. This phenomena is much more pronounced during springtime with a focus on May.

\subsection{June to August}

In summer (June-July-August, JJA) in the middle panel (Figure 3(g), Figure $3(\mathrm{~h})$ and Figure $3(\mathrm{i}))$, the atmospheric structure is almost identical to the spring 

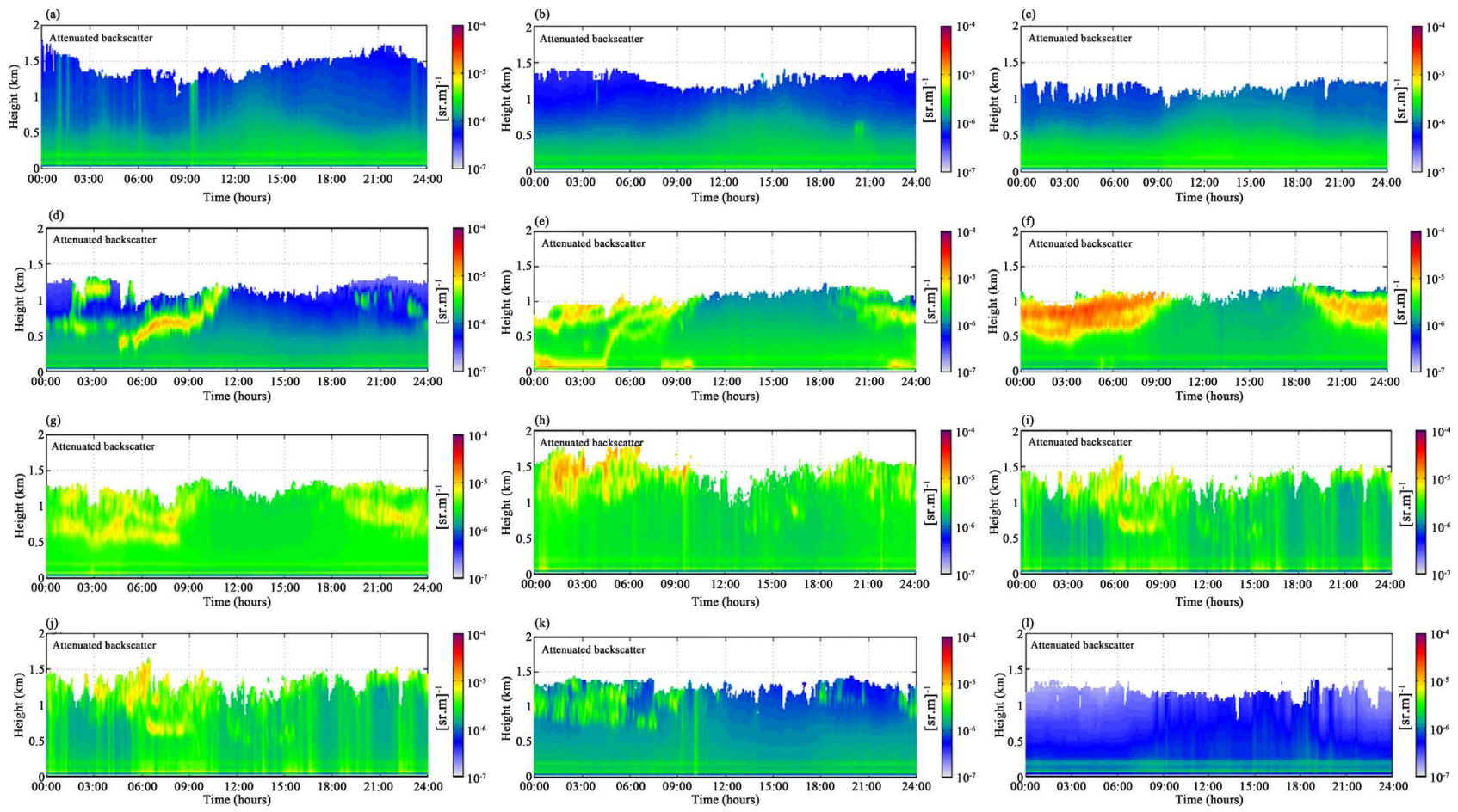

Figure 3. Diurnal cycle of monthly sliding average lidar profiles recorded in Dakar during 2012 to 2014 ((a) to (j)) and during the year 2018 for (k) and (l). The attenuated backscatter was calculated at the wavelength $905 \mathrm{~nm}$ and the subplot from (a) to (l) represent respectively the monthly average of from December to November.

situation. The much aerosol loading is located in the upper levels between $500 \mathrm{~m}$ and $1500 \mathrm{~m}$ asl. The dust layer is more elevated than during springtime where the upper layer was located between $500 \mathrm{~m}$ and $1000 \mathrm{~m}$ asl. This elevated aerosol layer can be associated to a stronger convective transport, which is more important in summer than during other seasons in the tropical regions [40]. The nocturnal aerosol layer reaches highest levels between June and August. During day, the lower part of the troposphere is heavier in aerosol compare to spring, but the stratification of the atmosphere is still observed. In this season, the destruction of the boundary layer development during daytime is not only due to stratification of the atmosphere which inducing by the oceanic air masses. In addition to these latter thermodynamical features, the rainfall can play an important role in the vertical distribution of aerosols over West Africa. The aerosols suspended can be scavenging by convective and stratiform precipitation [41].

\subsection{September to November}

In autumn (September-October-November, SON) the vertical aerosol distribution is very similar to the summer situation in the lower panel (Figure 3(j), Figure 3(k), and Figure 3(1)), but the aerosol layer is less thick. The heavy aerosol layer is located around $1000 \mathrm{~m}$ asl during nighttime (Figure 3(j), Figure 3(k)). This strong attenuated backscatter signal indicates a tick aerosol layer, in agreement with Senghor et al. [37], Adams et al. [30], and Bado et al. [42]. Léon et al. [43] have observed from lidar measurements a thick aerosol layer located be- 
tween 1000 and $2000 \mathrm{~m}$ at the Western coastal of Dakar in September 2001. In West Africa, November is a period when the ground observations show a minimum dust loading in the atmosphere (Figure 3(1)) in agreement with Léon et al. [36].

The wet season is going until October in Senegal [44] and then the precipitation impacted the vertical distribution aerosols. The surface humidity is relatively high impacting dust emissions over West Africa. To avoid the effect of scavenging on the aerosol layer and in order to isolate clearly the impact of the local atmospheric circulation on mineral dust layer, we only considered hereafter the dry season (winter and spring) for discussion.

\section{Atmospheric Vertical Stratification}

In this section, we focus our investigation in both months, December and May which represent respectively the winter and the spring seasons. These both selected months allow us to show a very clear contrast on the vertical aerosol distribution over West Africa coastal. The study of the dust plumes or the aerosol layers in general is more difficult in this area because the tropospheric structure is determined by an interaction between different wind regimes. The transport of mineral dust occurs during the whole year over Dakar [36], since it is located in the pathways of desert dust aerosols. The meso-scale circulation interacts with the local dynamic at the coastlines due to the sea-breeze circulation [12].

In December the lower values of the relative humidity are located between 500 $\mathrm{m}$ and $1500 \mathrm{~m}$ (Figure 4(a)). The atmosphere is drier during the daytime with a minimum humidity of $20 \%$ than nighttime. The dryer air masses in daytime (Figure $4(\mathrm{a})$ ) are associated with a strong development of the atmospheric boundary layer shown by the attenuated backscatter coefficient (Figure 3(a)). The well mixed layer is composed by a combination of mineral dust from local emissions and desert dusts removed in the atmosphere by dry deposition during their westward transport and the degradation of the ELLJ in early morning [16]. The dust aerosols make the atmosphere dryer inducing a low relative humidity [45] [46] [47]. During night, air masses coming from the ocean bring moisture in the troposphere and producing stratification near surface (Figure 5(a)).

In contrast, Figure 4 (b) shows a slight inversion of the relative humidity with a minimum of $21 \%$ between 500 and $1000 \mathrm{~m}$ in spring during night. These lower values of the relative humidity during night indicate a majority presence of mineral dust with a high contribution to the aerosol optical depth (AOD) [48]. The lower values of the relative humidity during night in MAM are well correlated with the attenuated backscatter coefficient which occurred between 21 and 09 UTC. These heavy aerosol concentrations are associated to a westward Sahara dust transported in NLLJ [17] which is located between 500 and $1000 \mathrm{~m}$ asl over Dakar (Figure 4(f)).

In MAM, between 08 UTC and 14 UTC the air masses are coming from northeastern indicated a continental air masses (Figure 5(a)). The winds coming 

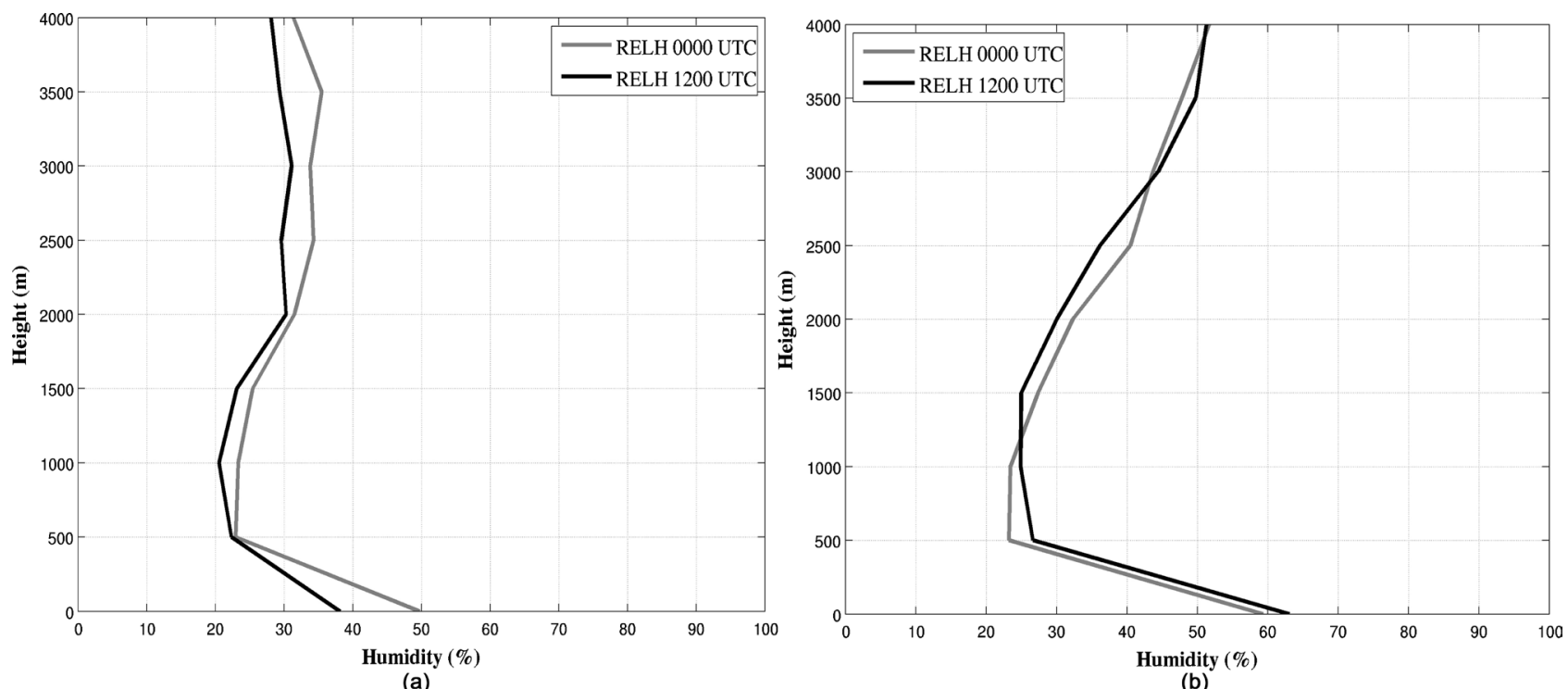

Figure 4. The relative humidity $(\mathrm{RH})$ measured by the soundings at Dakar-Yoff. Both measurements by day at 00 UTC gray lines and at 12 UTC black lines. The left panel (Figure 4(a)) and the right panel (Figure 4(b)) show respectively the mean vertical profile of RH between 2012 to 2014 over Dakar. The vertical profile is averaged by a gate of $100 \mathrm{~m}$ in the altitude.

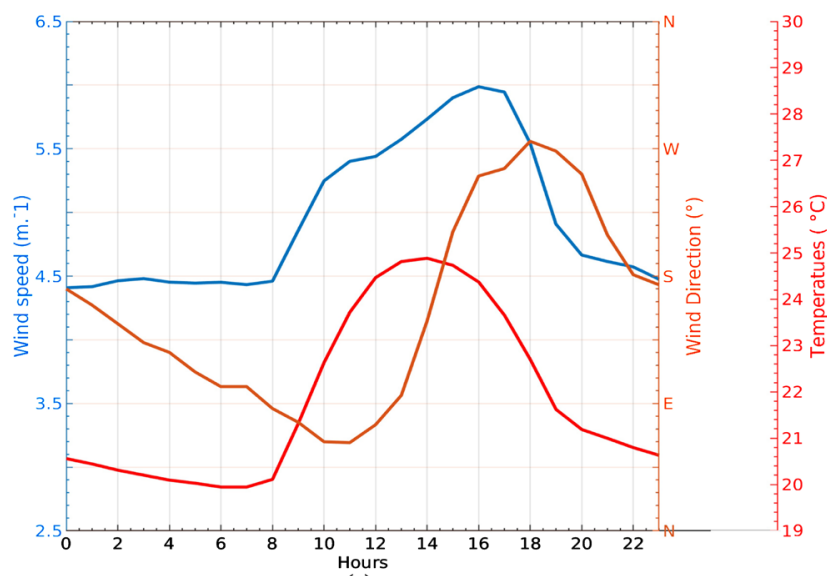

(a)

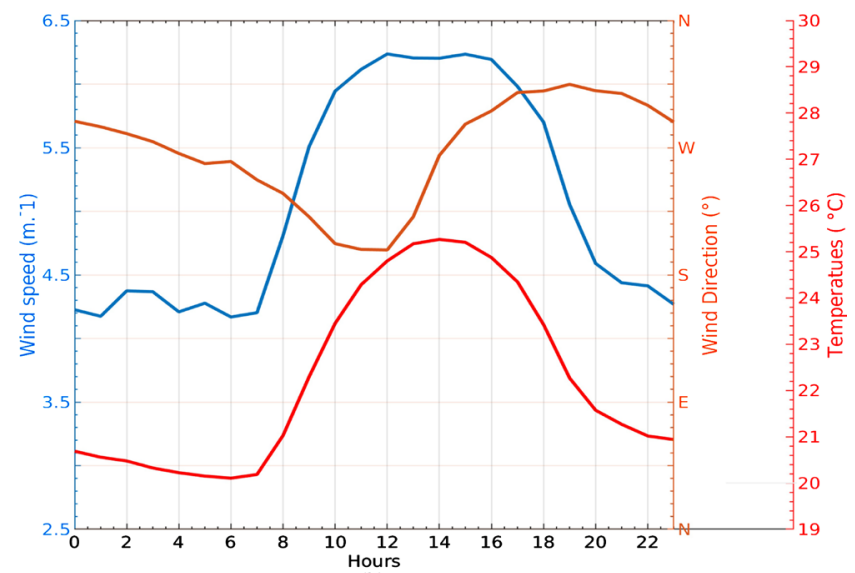

(b)

Figure 5. Seasonal variability of diurnal cycle for the horizontal wind speed (blue), wind direction (brown), and surface temperature (red) in Dakar between 2012 to 2014. DJF is represented on the left panel (Figure 5(a)) and MAM on the right panel (Figure $5(\mathrm{~b})$ ).

from southwestern have shown a clear marine air masses (Figure 5(b)). The oceanic air masses affects the tick dust aerosol layer near surface (Figure 3(f)) in agreement with McKendry et al. [14], Petzold et al. [12], and Rivellini et al. [15].

The vertical wind profile shows a stronger wind below $500 \mathrm{~m}$ than above 500 $\mathrm{m}$ (Figure 6). The wind speed is more important in DJF than in MAM (Figure 6(a)) for the both daily sounding (00 UTC and 12 UTC). The maximum wind is registered with a velocity of $25 \mathrm{~m} / \mathrm{s}$ for the sounding at 12 UTC and a value of 21 $\mathrm{m} / \mathrm{s}$ at 00 UTC. For both seasons, air mass at the altitude comes from the continent, north-east in winter and south-east in spring, transporting Saharan dust to the Atlantic Ocean (Figure 6(b)).

The seasonality is clearer in the wind direction in DJF than MAM. In agreement 


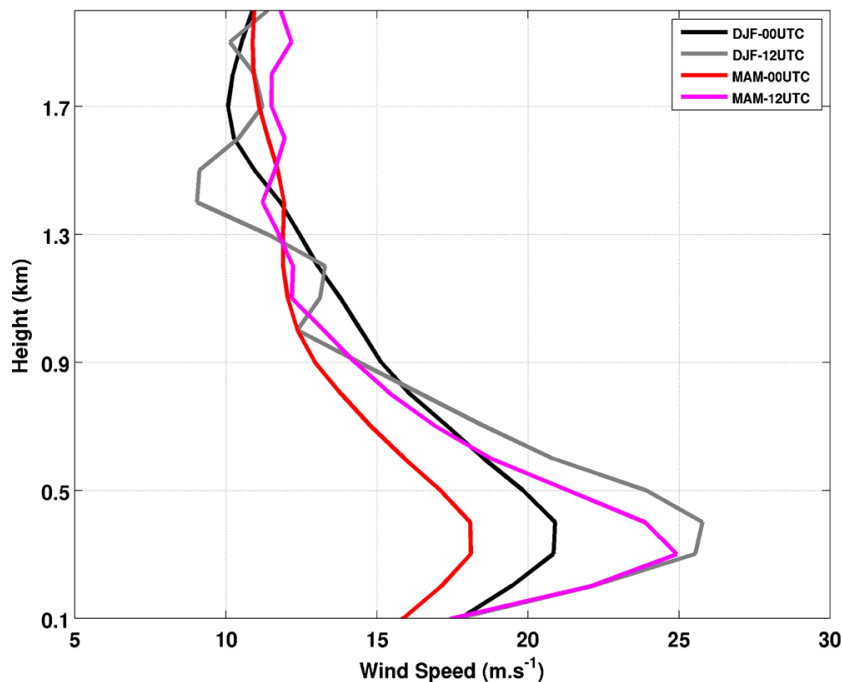

(a)

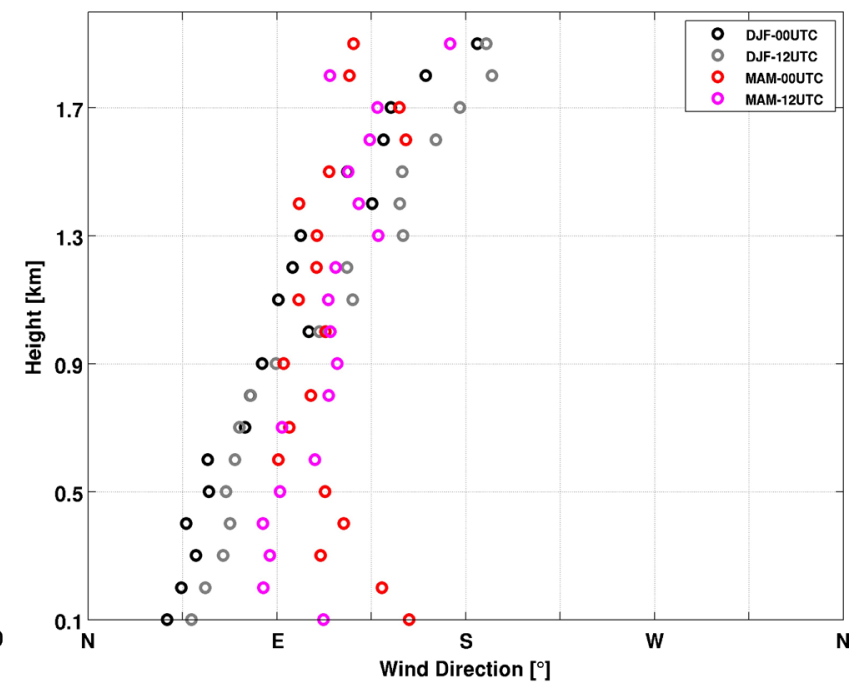

(b)

Figure 6. The vertical profile of the Wind speed (Figure (a)) and wind direction (Figure 6(b)) over Dakar for DJF and MAM from 2012 to 2014. The profiles have represented for the daily both sounding at 00 UTC and 12 UTC. The air masses layers are averaged by a gate of $100 \mathrm{~m}$ ASL.

with [37] [49], the wind direction in the lower levels (below $500 \mathrm{~m}$ ) is southern-east during MAM and northern-east during the DJF. The wind direction obtained near the surface in winter shows a clear signature of the Harmattan.

\section{Conclusion}

The analysis of the aerosol profiles based on the attenuated backscatter shows a clear seasonal cycle with a heavy atmospheric dust loading located between 500 $\mathrm{m}$ and $1000 \mathrm{~m}$ asl. The offshore advection during DJF and the occurrence of the local turbulence in daytime bring much dust loading in the atmosphere over the West Africa coastal. On the other hand, the onshore advection near surface and the westward advection between $500 \mathrm{~m}$ and $1000 \mathrm{~m}$ (Figure 5(b)) indicate a strong impact of the sea-breeze circulation which occurs in MAM and inducing mainly a strong dilution of the aerosol concentration near continental surface (Figure 3(f)). The complex relationship between the weather forcing and the atmospheric aerosol loading induces a dryer atmosphere (Figure 3(d), Figure 3(e) and Figure 3(f)). The dryer atmosphere is mainly stronger during nighttime in MAM due to the thickness and intense westward dust advection in the nocturnal jet. During JJA, the mineral dust layer near surface measured by the ceilometer can reach a maximum height of the boundary layer with a top up to $1500 \mathrm{~m}$. This thick dust layer could be induced by the seasonal migration of the Inter-tropical Convergence Zone which promotes the violent convective systems in Sahel area.

\section{Acknowledgements}

This research is supported by the international laboratory ECLAIRS2.

We are very grateful to Gregory S. Jenkins for the collaboration between the 
Laboratoire de Physique de l'Atmosphère et de l'Océan Siméon-Fongang (LPAO-SF), École Supérieure Polytechnique (ESP) de l'Université Cheikh Anta Diop (UCAD), Dakar, Senegal and the Department of Physics and Astronomy, Howard University, Washington, District of Columbia, USA. We are very thankful to Mamadou Drame for the initial management of the lidar's station. We thank Universidad Complutense de Madrid and interMET for installation and maintenance of CL31 through cooperation programs Calls IIX, IX and XII.

\section{Conflicts of Interest}

The authors declare no conflicts of interest regarding the publication of this paper.

\section{References}

[1] D’almeida, G.A. (1986) A Model for Saharan Dust Transport. Journal of Climate and Applied Meteorology, 25, 903-916. https://doi.org/10.1175/1520-0450(1986)025<0903:AMFSDT>2.0.CO;2

[2] Huneesus, N., Schulz, M., Balkanski, Y., Griesfeller, J., Kinne, S., Prospero, J., Bauer, S., Boucher, O., Chin, M., Dentener, F., Diehi, T., Easter, R., Fillmore, D., Ghan, S., Ginoux, P., Grini, A., Horowitz, L., Koch, D., Krol, M.C., Landing, W., Liu, X., Mahowald, N., Miller, R., Morcrette, J.J., Myhre, G., Penner, J.E., Perlwitz, J., Stier, P., Takemura, T. and Zender, C. (2010) Global Dust Model Intercomparison in AeroCom Phase I. Atmospheric Chemistry and Physics, 11, 7781-7816. https://doi.org/10.5194/acp-11-7781-2011

[3] Andreae, M.O. (1996) Raising Dust in the Greenhouse. Nature, 380, 389. https://doi.org/10.1038/380389a0

[4] Prospero, J.M. (2006) Saharan Dust Impacts and Climate Change. Oceanography, 19, 60. https://doi.org/10.5670/oceanog.2006.65

[5] Griffin, D.W. (2007) Atmospheric Movement of Microorganisms in Clouds of Desert Dust and Implications for Human Health. Clinical Microbiology Reviews, 20, 459-477. https://doi.org/10.1128/CMR.00039-06

[6] Martiny, N. and Chiapello, I. (2013) Assessments for the Impact of Mineral Dust on the Meningitis Incidence in West Africa. Atmospheric Environment, 70, 245-253. https://doi.org/10.1016/j.atmosenv.2013.01.016

[7] Moulin, C. (1997) Transport atmosphérique des poussières africaines sur la Méditerranée et l'Atlantique: Climatologie satellitale à partir des images Météosat VIS (1983-1994) et relations avec le climat. 246 p. https://pascal-francis.inist.fr/vibad/index.php?action=getRecordDetail\&idt=141968 $\underline{12}$

[8] Chiapello, I. and Moulin, C. (2002) TOMS and METEOSAT Satellite Records of the Variability of Saharan Dust Transport over the Atlantic during the Last Two Decades (1979-1997). Geophysical Research Letters, 29, 17-1-17-4. https://doi.org/10.1029/2001GL013767

[9] Prospero, J.M. and Lamb, P.J. (2003) African Droughts and Dust Transport to the Caribbean: Climate Change Implications. Science, 302, 1024-1027. https://doi.org/10.1126/science.1089915

[10] Mulitza, S., Heslop, D., Pittauerova, D., Fischer, H.W., Meyer, I., Stuut, J.-B., Zabel, M., Mollenhauer, G., Collins, J.A., Kuhnert, H. and Schulz, M. (2010) Increase in 
African Dust Flux at the Onset of Commercial Agriculture in the Sahel Region. Nature, 466, 226-228. https://doi.org/10.1038/nature09213

[11] Pu, B. and Cook, K.H. (2010) Dynamics of the West African Westerly Jet. Journal of Climate, 23, 6263-6276. https://doi.org/10.1175/2010JCLI3648.1

[12] Petzold, A., Veira, A., Mund, S., Esselborn, M., Kiemle, C., Weinzierl, B., Hamburger, T., Ehret, G., Lieke, K. and Kandler, K. (2011) Mixing of Mineral Dust with Urban Pollution Aerosol over Dakar (Senegal): Impact on Dust Physico-Chemical and Radiative Properties. Tellus B, 63, 619-634.

https://doi.org/10.1111/j.1600-0889.2011.00547.x

[13] Skakalova, T.S., Savov, P.B., Grigorov, I.V. and Kolev, I.N. (2003) Lidar Observation of Breeze Structure during the Transition Periods at the Southern Bulgarian Black Sea Coast. Atmospheric Environment, 37, 299-311. https://doi.org/10.1016/S1352-2310(02)00919-6

[14] McKendry, I., Strawbridge, K. and Jones, A. (2011) Continuous 1064/532 nm Lidar Measurements (CORALNet-UBC) in Vancouver, British Columbia: Selected Results from a Year of Operation. Atmosphere-Ocean, 49, 32-40. https://doi.org/10.1080/07055900.2011.557799

[15] Rivellini, L.H., Chiappelo, I., Tison, E., Fourmenti, M., Féron, A., Diallo, A., N'diaye, T., Goloub, P., Canonaco, F., Prévôt, A.S.H. and Riffault, V. (2017) Chemical Characterization and Source Apportionment of Submicron Aerosols Measured in Senegal during the 2015 SHADOW Campaign. Atmospheric Chemistry and Physics, 17, 10291-10314. https://doi.org/10.5194/acp-17-10291-2017

[16] Schepanski, K.I., Todd, M., Heinold, B., Bönisch, G., Laurent, B. and Macke, A. (2009) Meteorological Processes Forcing Saharan Dust Emission Inferred from MSG-SEVIRI Observations of Subdaily Dust Source Activation and Numerical Models. Journal of Geophysical Research: Atmospheres, 114, D10201. https://doi.org/10.1029/2008JD010325

[17] Heese, B. and Wiegner, M. (2008) Vertical Aerosol Profiles from Raman Polarization Lidar Observations during the Dry Season AMMA Field Campaign. Journal of Geophysical Research: Atmospheres, 113, D00C11. https://doi.org/10.1029/2007JD009487

[18] Diokhane, A.M., Jenkins, G.S., Manga, N., Drame, M.S. and Mbodji, B. (2016) Linkages between Observed, Modeled Saharan Dust Loading and Meningitis in Senegal during 2012 and 2013. International Journal of Biometeorology, 60, 557-575. https://doi.org/10.1007/s00484-015-1051-5

[19] Choobari, O.A., Zawar-Reza, P. and Sturman, A. (2014) The Global Distribution of Mineral Dust and Its Impacts on the Climate System: A Review. Atmospheric Research, 138, 152-165. https://doi.org/10.1016/j.atmosres.2013.11.007

[20] Cuesta, J., Marsham, J.H., Parker, D.J. and Flamant, C. (2009) Dynamical Mechanisms Controlling the Vertical Redistribution of Dust and the Thermodynamic Structure of the West Saharan Atmospheric Boundary Layer during Summer. Atmospheric Science Letters, 10, 34-42. https://doi.org/10.1002/asl.207

[21] Guerrero-Rascado, J.L., Costa, M.J., Bortoli, D., Silva, A.M., Lyamani, H. and Alados-Arboledas, L. (2010) Infrared Lidar Overlap Function: An Experimental Determination. Optics Express, 18, 20350-20369.

https://doi.org/10.1364/OE.18.020350

[22] Tsaknakis, G., Papayannis, A., Kokkalis, P., Amiridis, V., Kambezidis, H., Mamouri, R., Georgoussis, G. and Avdikos, G. (2011) Inter-Comparison of Lidar and Ceilometer Retrievals for Aerosol and Planetary Boundary Layer Profiling over Athens, 
Greece. Atmospheric Measurement Techniques, 4, 1261-1273. https://doi.org/10.5194/amt-4-1261-2011

[23] Munkel, C. and Rasanen, J. (2004) New Optical Concept for Commercial Lidar Ceilometers Scanning the Boundary Layer. Remote Sensing of Clouds and the Atmosphere IX, Volume 5571, 364-374. https://doi.org/10.1117/12.565540

[24] Münkel, C., Eresmaa, N., Räsänen, J. and Karppinen, A. (2007) Retrieval of Mixing Height and Dust Concentration with Lidar Ceilometer. Boundary-Layer Meteorology, 124, 117-128. https://doi.org/10.1007/s10546-006-9103-3

[25] Emeis, S., Schäfer, K. and Münkel, C. (2008) Surface-Based Remote Sensing of the Mixing-Layer Height-A Review. Meteorologische Zeitschrift, 17, 621-630. https://doi.org/10.1127/0941-2948/2008/0312

[26] Guide, V.U.S. (2010) Vaisala Ceilometer CL31. Vaisala Oyj, Helsinki.

[27] Kaufman, Y., Tanré, D., Léon, J.F. and Pelon, J. (2003) Retrievals of Profiles of Fine and Coarse Aerosols Using Lidar and Radiometric Space Measurements. IEEE Transactions on Geoscience and Remote Sensing, 41, 1743-1754. https://doi.org/10.1109/TGRS.2003.814138

[28] Cuesta, J., Edouart, D., Mimouni, M., Flamant, P.H., Loth, C., Gilbert, F., Marnas, F., Bouklila, A., Kharef, M., Ouchène, B., Kadi, M. and Flamant, C. (2008) Multiplatform Observations of the Seasonal Evolution of the Saharan Atmospheric Boundary Layer in Tamanrasset, Algeria, in the Framework of the African Monsoon Multidisciplinary Analysis Field Campaign Conducted in 2006. Journal of Geophysical Research: Atmospheres, 113, D00C07. https://doi.org/10.1029/2007JD009417

[29] Eck, T.F., Holben, B.N., Reid, J.S., Mukelabai, M.M., Piketh, S.J., Torres, O., Jethva, H.T., Hyer, E.J., Ward, D.E., Dubovik, O., Sinyuk, A., Schafer, J.S., Giles, M.D., Sorokin, M., Smirnov, A. and Dubovik, O. (2013) A Seasonal Trend of Single Scattering Albedo in Southern African Biomass-Burning Particles: Implications for Satellite Products and Estimates of Emissions for the World's Largest Biomass-Burning Source. Journal of Geophysical Research: Atmospheres, 118, 6414-6432. https://doi.org/10.1002/jgrd.50500

[30] Adams, A.M., Prospero, J.M. and Zhang, C. (2012) CALIPSO-Derived Three- Dimensional Structure of Aerosol over the Atlantic Basin and Adjacent Continents. Journal of Climate, 25, 6862-6879. https://doi.org/10.1175/JCLI-D-11-00672.1

[31] Hunt, W.H., Winker, D.M., Vaughan, M.A., Powell, K.A., Lucker, P.L. and Weimer, C. (2009) CALIPSO Lidar Description and Performance Assessment. Journal of Atmospheric and Oceanic Technology, 26, 1214-1228. https://doi.org/10.1175/2009JTECHA1223.1

[32] Jenkins, G., Kucera, P., Joseph, E., Fuentes, J., Gaye, A., Gerlach, J., Roux, F., Viltard, N., Papazzoni, M., Protat, A., Bouniol, D., Reynolds, A., Arnault, J., Badiane, D., Kebe, F., Camara, M., Sall, S., Ndiaye, S.A. and Deme, A. (2010) Coastal Observations of Weather Features in Senegal during the African Monsoon Multidisciplinary Analysis Special Observing Period 3. Journal of Geophysical Research: Atmospheres, 115, D18108. https://doi.org/10.1029/2009JD013022

[33] Ndoye, S., Capet, X., Estrade, P., Sow, B., Dagorne, D., Lazar, A., Gaye, A. and Brehmer, P. (2014) SST Patterns and Dynamics of the Southern Senegal-Gambia Upwelling Center. Journal of Geophysical Research: Oceans, 119, 8315-8335. https://doi.org/10.1002/2014JC010242

[34] Weinzierl, B., Ansmann, A., Prospero, J.M., Althausen, D., Benker, N., Chouza, F., Dollner, M., Farrell, D., Fomba, W.K., Freudenthaler, J.M., Gasteiger, J., Grob, S., 
Haarig, M., Heinold, B., Kandler, K., Kristensen, T.B., Bracero, O.L.M., Muller, T., Reitebuch, O., Sauer, D., Schafler, A., Schepanski, K., Spanu, A., Tegen, I., Toledano, C. and Walser, A. (2017) The Saharan Aerosol Long-Range Transport and Aerosol-Cloud-Interaction Experiment: Overview and Selected Highlights. Bulletin of the American Meteorological Society, 98, 1427-1451.

https://doi.org/10.1175/BAMS-D-15-00142.1

[35] Doumbia, E.H.T. (2012) Caractérisation physico-chimique de la pollution atmosphérique en Afrique de l'Ouest et étude d'impact sur la santé. Doctoral Dissertation, Université de Toulouse, Université Toulouse III-Paul Sabatier.

[36] Léon, J.-F., Derimian, Y., Chiapello, I., Tanré, D., Podvin, T., Chatenet, B., Diallo, A. and Deroo, C. (2009) Aerosol Vertical Distribution and Optical Properties over M'Bour (16.96 W 14.39 N), Senegal from 2006 to 2008. Atmospheric Chemistry and Physics, 9, 9249-9261. https://doi.org/10.5194/acp-9-9249-2009

[37] Senghor, H., Machu, É., Hourdin, F. and Gaye, A.T. (2017) Seasonal Cycle of Desert Aerosols in Western Africa: Analysis of the Coastal Transition with Passive and Active Sensors. Atmospheric Chemistry and Physics, 17, 8395-8410. https://doi.org/10.5194/acp-17-8395-2017

[38] Wu, X.F., Zhang, S.B., Gao, H., Wei, J.J., Zou, Y.C., Lei, W.H., Zhang, B., Dai, Z.G. and Mészaros, P. (2016) Constraints on the Photon Mass with Fast Radio Bursts. The Astrophysical Journal Letters, 822, L15. https://doi.org/10.3847/2041-8205/822/1/L15

[39] Markowicz, K.M., Flatau, P.J., Kardas, A.E., Remiszewska, J., Stelmaszczyk, K. and Woeste, L. (2008) Ceilometer Retrieval of the Boundary Layer Vertical Aerosol Extinction Structure. Journal of Atmospheric and Oceanic Technology, 25, 928-944. https://doi.org/10.1175/2007JTECHA1016.1

[40] Liu, H., Jacob, D.J., Bey, I. and Yantosca, R.M. (2001) Constraints from $210 \mathrm{~Pb}$ and 7Be on Wet Deposition and Transport in a Global Three-Dimensional Chemical Tracer Model Driven by Assimilated Meteorological Fields. Journal of Geophysical Research: Atmospheres, 106, 12109-12128. https://doi.org/10.1029/2000JD900839

[41] Pilon, R., Grandpeix, J.-Y. and Heinrich, P. (2015) Representation of Transport and Scavenging of Trace Particles in the Emanuel Moist Convection Scheme. Quarterly Journal of the Royal Meteorological Society, 141, 1244-1258. https://doi.org/10.1002/qj.2431

[42] Bado, N., Ouédraogo, A., Guengané, H., Ky, T.S.M., Bazyomo, S.D., Korgo, B., Dramé, M.S., Sall, S.M., Kieno, F.P. and Bathiebo, D.J. (2019) Climatological Analysis of Aerosols Optical Properties by Airborne Sensors and in Situ Measurements in West Africa: Case of the Sahelian Zone. Open Journal of Air Pollution, 8, 118-135. https://doi.org/10.4236/ojap.2019.84007

[43] Léon, J.-F., Pelon, J., Tanré, D., Kaufman, Y., Goloub, P., Haywood, J. and Chatenet, B. (2003) Profiling of a Saharan Dust Outbreak Based on a Synergy between Active and Passive Remote Sensing. Journal of Geophysical Research, 108, 8575. https://doi.org/10.1029/2002JD002774

[44] Uddenfeldt Wort, U. (2007) An Analysis of Seasonality and Birth Outcomes in Highly Malarious Areas of Tanzania. Rozenberg Publishers, Amsterdam.

[45] Dunion, J.P. and Marron, C.S. (2008) A Reexamination of the Jordan Mean Tropical Sounding Based on Awareness of the Saharan Air Layer: Results from 2002. Journal of Climate, 21, 5242-5253. https://doi.org/10.1175/2008JCLI1868.1

[46] Wong, S., Dessler, A.E., Mahowald, Yang, P. and Feng, Q. (2009) Maintenance of Lower Tropospheric Temperature Inversion in the Saharan Air Layer by Dust and 
Dry Anomaly. Journal of Climate, 22, 5149-5162. https://doi.org/10.1175/2009JCLI2847.1

[47] Tsamalis, C., Chédin, A., Pelon, J. and Capelle, V. (2013) The Seasonal Vertical Distribution of the Saharan Air Layer and Its Modulation by the Wind. Atmospheric Chemistry and Physics, 13, 11235-11257.

https://doi.org/10.5194/acp-13-11235-2013

[48] Carlson, T.N. and Prospero, J.M. (1972) The Large-Scale Movement of Saharan Air Outbreaks over the Northern Equatorial Atlantic. Journal of Applied Meteorology, 11, 283-297. https://doi.org/10.1175/1520-0450(1972)011<0283:TLSMOS>2.0.CO;2

[49] Marticorena, B., Chatenet, B., Rajot, J.-L., Traoré, S., Coulibaly, M., Diallo, A., Koné, I., Maman, A., NDiaye, T. and Zakou, A. (2010) Temporal Variability of Mineral Dust Concentrations over West Africa: Analyses of a Pluriannual Monitoring from the AMMA Sahelian Dust Transect. Atmospheric Chemistry and Physics, 10, 8899-8915. https://doi.org/10.5194/acp-10-8899-2010 